\title{
Recent Weed Control, Weed Management, and Integrated Weed Management
}

\author{
K. Neil Harker and John T. O’Donovan*
}

\begin{abstract}
Integrated weed management (IWM) can be defined as a holistic approach to weed management that integrates different methods of weed control to provide the crop with an advantage over weeds. It is practiced globally at varying levels of adoption from farm to farm. IWM has the potential to restrict weed populations to manageable levels, reduce the environmental impact of individual weed management practices, increase cropping system sustainability, and reduce selection pressure for weed resistance to herbicides. There is some debate as to whether simple herbicidal weed control programs have now shifted to more diverse IWM cropping systems. Given the rapid evolution and spread of herbicideresistant weeds and their negative consequences, one might predict that IWM research would currently be a prominent activity among weed scientists. Here we examine the level of research activity dedicated to weed control techniques and the assemblage of IWM techniques in cropping systems as evidenced by scientific paper publications from 1995 to June 1, 2012. Authors from the United States have published more weed and IWM-related articles than authors from any other country. When IWM articles were weighted as a proportion of country population, arable land, or crop production, authors from Switzerland, the Netherlands, New Zealand, Australia, and Canada were most prominent. Considerable evidence exists that research on nonherbicidal weed management strategies as well as strategies that integrate other weed management systems with herbicide use has increased. However, articles published on chemical control still eclipse any other weed management method. The latter emphasis continues to retard the development of weed science as a balanced discipline.

Key words: Alternative weed control, biological control, chemical weed control, cultural weed control, integrated cropping systems, integrated pest management, physical weed control, preventative weed control, weed resistance to herbicides.
\end{abstract}

El manejo integrado de malezas (IWM) puede ser definido como un enfoque holístico del manejo de malezas que integra diferentes métodos de control para brindar al cultivo una ventaja sobre las malezas. Esto es practicado globalmente con niveles de adopción que varían de finca a finca. El IWM tiene el potencial de restringir las poblaciones de malezas a niveles manejables, reducir el impacto ambiental de prácticas individuales de manejo de malezas, incrementar la sostenibilidad de los sistemas de cultivos y reducir la presión de selección sobre la resistencia a herbicidas de las malezas. Existe cierto debate acerca de si programas de control de malezas basados simplemente en herbicidas, ahora se han convertido a sistemas de cultivos con IWM más diversos. Dada la rápida evolución y dispersión de malezas resistentes a herbicidas y sus consecuencias negativas, uno podría predecir que la investigación en IWM sería actualmente una actividad prominente entre científicos de malezas. Aquí examinamos el nivel de actividad investigativa dedicada a técnicas de control de malezas y al ensamblaje de técnicas de IWM en sistemas de cultivos, usando como evidencia la publicación de artículos científicos desde 1995 al 1 de Junio, 2012. Autores de los Estados Unidos han publicado más artículos relacionados a malezas y a IWM que autores de cualquier otro país. Cuando se ajustó el peso de los artículos de IWM como proporción de la población del país, tierras arables o producción de cultivos, autores de Suiza, Holanda, Nueva Zelanda, Australia y Canadá fueron los más prominentes. Existe considerable evidencia de que ha incrementado la investigación sobre estrategias noherbicidas de manejo de malezas y también sobre las estrategias que integran otros sistemas de manejo de malezas con el uso de herbicidas. Sin embargo, los artículos publicados sobre control químico todavía eclipsan cualquier otro método de manejo de malezas. Este último énfasis continúa retrasando el desarrollo de la ciencia de malezas como una disciplina balanceada.

Herbicides are the dominant tool used for weed control in modern agriculture; they are highly effective on most weeds but are not a complete solution to the complex challenge that weeds present. The overuse of herbicides has led to the rapid evolution of herbicide-resistant (HR) weeds (Beckie 2006; Egan et al. 2011; Powles and Yu 2010). Globally, there are 383 HR weed biotypes among 208 HR weed species (Heap

\footnotetext{
DOI: 10.1614 /WT-D-12-00109.1

* Research Scientists, Agriculture and Agri-Food Canada, Lacombe Research Centre, 6000 C\&E Trail, Lacombe, Alberta T4L 1W1, Canada. Corresponding author's E-Mail: neil.harker@agr.gc.ca
}

2012). Weeds resistant to the most widely used herbicide in the world, glyphosate, have been confirmed in 20 countries (23 species) (Heap 2012). In addition, multiple herbicide resistance within single biotypes is widespread. Ever-increasing populations of $\mathrm{HR}$ weeds, especially those with multiple herbicide resistance, have pressured weed researchers to develop management systems that are less dependent on herbicides (Powles and Matthews 1992). Given HR weed issues and consistent public pressure to reduce overall pesticide use, herbicide alternatives and true integrated weed 
management (IWM) strategies are urgently required now more than ever.

The importance of using alternatives to chemicals for weed control was recognized long ago. In 1929, in a meeting where spraying with sulfuric acid for mustard control was considered practicable, the chairman made the following conclusion: "The destruction of weeds by chemicals must of course be supplementary to crop rotation, summer fallowing and other control methods, which will always have a prominent place" (NRC 1929). Although summer fallow is no longer a desirable weed management practice in many areas, at such an early era of chemical weed management, the chairman was certainly astute in suggesting that chemicals must be supplementary to other weed control methods. Unfortunately, in modern agriculture, nonherbicidal weed control methods have not always held "a prominent place."

Many others have challenged weed researchers to increase emphasis on IWM systems and alternatives to herbicides. In 1992, Wyse suggested the need for "more emphasis on principles-based research that can provide the basic knowledge required to develop new weed control technology." He also stated that "non-chemical methods of weed control have not been researched extensively for almost $30 \mathrm{yr}$," an observation supported by other weed scientists (Altieri and Liebman 1988, Buhler 1999, Roush et al. 1990, Thill et al. 1991). Buhler (1999) and Hamill et al. (2004) suggested that a common goal for weed science should be to develop systems that give producers more flexibility and options. Buhler (1999) further challenged researchers with the statement that "we seldom examine the causes of the perpetual presence of weeds." Maxwell and O'Donovan (2007) stressed the need to identify the first principles of weed ecology and biology that relate to crop-weed interactions and demonstrate how they can be used to assess weed management alternatives including nonchemical approaches. Others have suggested the need to incorporate the various components of IWM into cropping, including user-friendly decision support systems (O'Donovan 1996; Swanton et al. 2008). More recently, Egan et al. (2011) noted that a diversity of chemical and nonchemical practices reduces herbicide use and offers a more robust weed-control system. Clearly, a diverse suite of weed research and outreach activities will be necessary for long-term weed management successes (Harker 2004).

Wyse (1992) noticed that most resources devoted to weed science have been directed to herbicide research. Therefore, he suggested that "weed science is currently perceived by many to be the science of herbicides rather than the science of weeds." Similarly, Thill et al. (1991) observed that many U.S. weed scientists publish more on herbicide-related research than all other areas combined. Since these comments were made, one might ask if resources and efforts of researchers have shifted from weed control with herbicides to the science of weeds and alternative strategies for weed management. Have nonchemical weed control methods been extensively researched? Is the discipline of weed science still perceived as the discipline of herbicides? Is the weed science contribution to agriculture still "truncated by intensive specialization and narrow expertise" (Zimdahl 1994)? Radosevich and Ghersa (1992) suggest that "weed scientists...need to think about how they think."
Zimdahl (1994) suggested that weed scientists should ask themselves: "who are you and where are you going?" The analysis of weed control, weed management, and IWMrelated publications in this review helps answer these questions and provides one measure of how well weed researchers have responded to the above challenges.

Weed "management" implies more than weed "control" and is an important choice of terms and direction (Buhler 1996; Zimdahl 1994). The "ruthless fight to the last weed" (Zimdahl 1994) is part of the weed control paradigm, whereas a weed management paradigm suggests greater consideration of thresholds, critical periods, environment, and possibly even social outcomes, before weed management methods are imposed. The next logical step is to integrate multiple weed management strategies into IWM systems. Numerous definitions have been applied to IWM and the broader area of integrated pest management (IPM). Some definitions incorporate economic and ecological goals in addition to the goal of integrating several weed management approaches. For example, Prokopy (2003) summarized the essence of many IPM definitions as follows: "...a decision-based process involving coordinated use of multiple tactics for optimizing the control of all classes of pests (insects, pathogens, weeds, vertebrates) in an ecologically and economically sound manner." An IWM definition from Australia has an HR weed focus: "to reduce selection pressure for resistance to any single control agent and to manage herbicide resistant weeds within a profitable system" (Sutherland 1991). However, for the purposes of this review, IWM is defined as the use of more than one weed management tactic (biological, chemical, cultural, or physical) during or surrounding a crop life cycle in a given field.

Successful IWM techniques are most likely to be discovered after biological characteristics and ecological behaviors of weeds have been elucidated. Many authors agree that the study of weeds themselves (weed biology and ecology) is absolutely essential to the development of useful IWM strategies (Altieri and Liebman 1988; Buhler 1996; Holt 1994; Liebman et al. 2001; Maxwell and Luschei 2004; Mortensen et al. 2000; Navas 1991; Radosevich and Ghersa 1992; Swanton et al. 2008; Wyse 1992; Zimdahl 1994). For example, Smith et al. (2009) recently united ecological and traditional crop-weed competition theories into a resource pool diversity hypothesis suggesting that more-diverse soil resource pools in more-diverse cropping systems increase crop competitiveness with weeds compared with less-diverse cropping systems. Radosevich and Ghersa (1992) observed that if we wish our cropping systems to be successful, stable, and profitable, weed researchers will also need to extend their influence into the basic disciplines of economics and sociology.

IWM systems may combine several different combinations of weed control methods. Although few of these systems combine all weed management methods (Figure 1A), many current IWM systems involve chemical and physical (especially tillage) (Figure 1B) or chemical and cultural (Figure 1C) methods. Unfortunately, the "integration" consisting of only chemical control components is common in modern cropping systems (Figure 1D). In this example, weed practitioners 
A
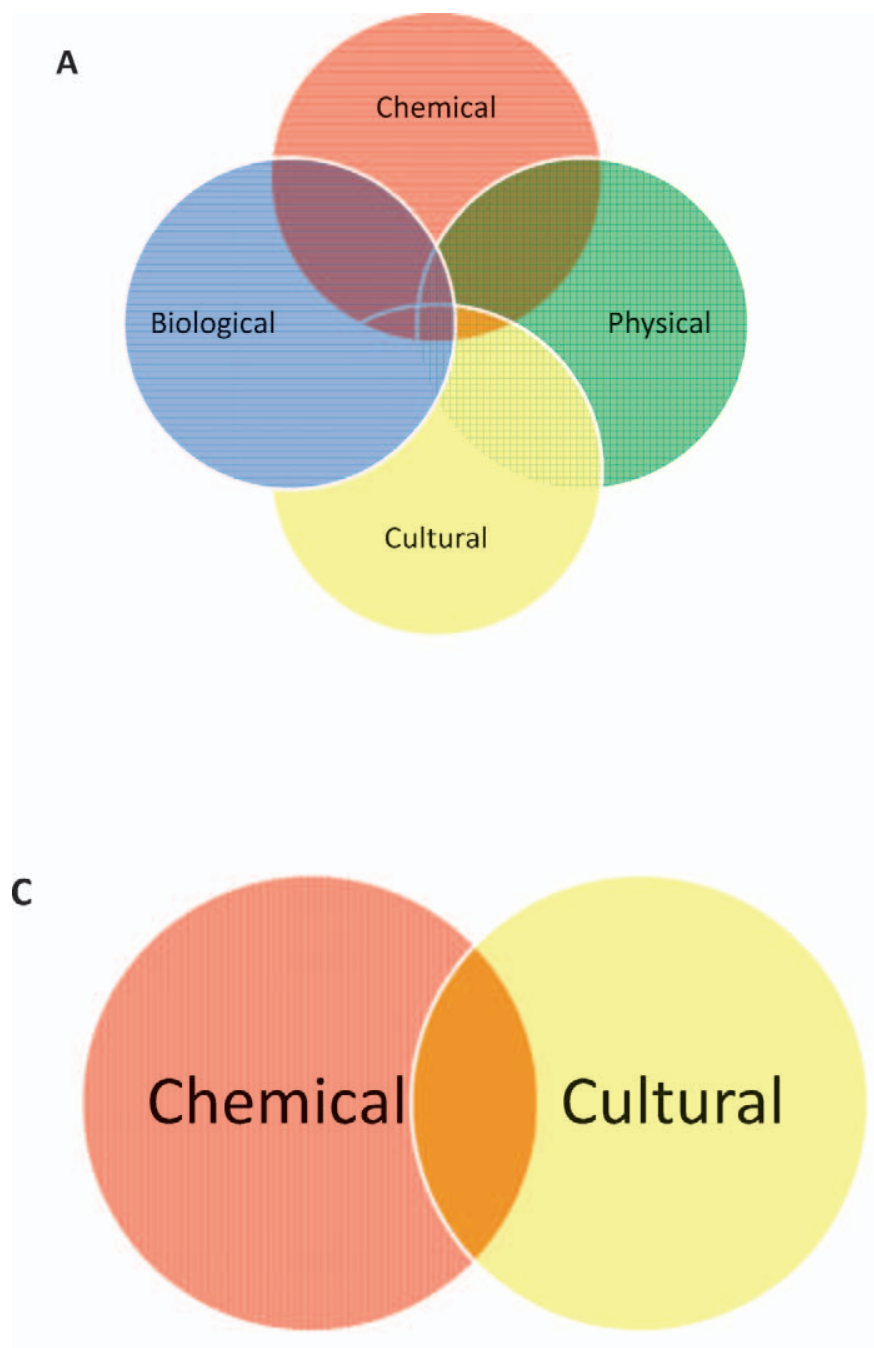

B

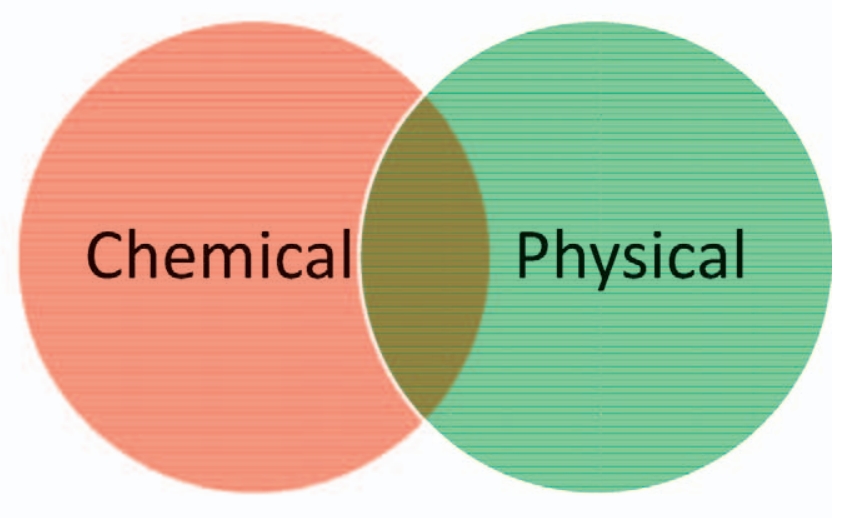

D

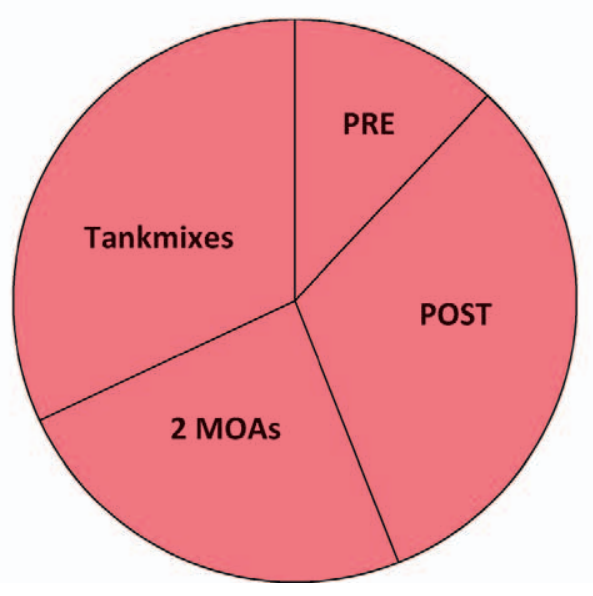

Figure 1. Some forms of true integrated weed management (IWM) (A-C) in contrast to integrated herbicide management (D).

recommend several ways of applying herbicides or recommend applying more than one herbicidal mode of action. Although these techniques are important, they are not IWM. The latter method (Figure 1D) is sometimes touted as an IWM program, but it is nothing more than a more complex form of managing weeds solely with herbicides, also known as integrated herbicide management (Harker et al. 2012). Perhaps the reason that so many weed scientists continue to only recommend herbicide solutions for weed resistance problems (Harker et al. 2012) is because they have the misguided feeling that IWM is simply a new term for herbicidal weed control (Walker and Buchanan 1982).

One might inappropriately conclude that IWM implementation means that herbicides should be avoided in preference for other weed management methods. However, IWM should not be about the exclusion of one method for another as much as it is about overall technique diversity. Any weed management method that is continuously repeated provides heavy selection pressure for weed adaptation and resistance to that practice. Intense and continuous barnyardgrass [Echinochloa crus-galli (L.) Beauv.] hand-weeding in rice
(Oryza sativa L.) allowed the selection of rice-mimic biotypes that "resisted" hand-weeding efforts (Barrett 1983). Therefore, weeds will likely resist any often-repeated weed management technique. In an IWM program, using a diversity of weed management methods is more important than striving to exclude any single method.

\section{Materials and Methods}

Our objective was to analyze weed-related articles published after 1994 to determine if IWM articles have increased relative to articles on weed control with herbicides, and to determine where IWM-related research has been conducted and published. We also considered articles published on weed biology, weed detection, and different methods of weed control as they provide knowledge and techniques for IWM systems. Our search was by no means intended to be an exhaustive review of all IWM techniques and systems. We utilized Scopus (http://www.scopus.com/search/form. url?zone $=$ TopNavBar\&origin=searchbasic) for our publica- 
tion queries given its excellent built-in analysis feature and publication coverage during the period we were interested in (1995 to June 1, 2012). Scopus "content coverage" details can be accessed on the same web page. For example, in May 2012, Scopus queries covered 19,500 titles, 18,500 of which were peer-reviewed journals. We conducted the following queries to access publication numbers and sources related to weed management, weed biology, weed detection, and several methods of weed management.

- TITLE-ABS-KEY("weed control") AND PUBYEAR > 1994

- TITLE-ABS-KEY("weed management") AND PUBYEAR > 1994

- TITLE-ABS-KEY("integrated weed management") AND PUBYEAR > 1994

- TITLE-ABS-KEY(weed* AND (biology OR ecology OR allelo* OR competition OR interference OR "critical period" OR duration OR population OR "spatial distribution")) AND PUBYEAR > 1994

- TITLE-ABS-KEY("weed detect*" OR (weed AND (vision OR sense OR robot*))) AND PUBYEAR > 1994

- TITLE-ABS-KEY(prevent* AND (weed* OR "weed control" OR "weed management")) AND PUBYEAR > 1994

- TITLE-ABS-KEY(biological AND ("weed control" OR "weed management")) AND PUBYEAR > 1994

- TITLE-ABS-KEY((chemical OR herbicid*) AND ("weed control" OR "weed management")) AND PUBYEAR > 1994

- TITLE-ABS-KEY((cultural OR "competitive cultivar" OR "competitive variety" OR "seed vigo*" OR "seed* rate*" OR "sow* rate" "crop densit*" OR "cover crop*" OR "smother crop*" OR "green manur*" OR "row spac*" OR "crop rotation*" OR "crop diversity" OR intercrop* OR "clean* seed" OR "certified seed" OR fertili*) AND ("weed control" OR "weed management")) AND PUBYEAR > 1994

- TITLE-ABS-KEY((physical OR mechanical OR till* OR cultivat* OR hoe* OR mow* OR thermal OR flam* OR steam* OR "seed destruct*") AND ("weed control" OR "weed management")) AND PUBYEAR > 1994

- TITLE-ABS-KEY((alternative OR organic OR holistic OR "low input" OR harvest*) AND ("weed control" OR "weed management")) AND PUBYEAR > 1994

We chose to limit our search to those articles published after 1994. The time period after 1994 allowed us to access weed scientists' response to the challenges issued by Wyse (1992) and Zimdahl (1994). Furthermore, the beginning of 1995 immediately precedes the introduction of HR crops (Duke 2005) and also marks the beginning of the relatively rapid increase of weed resistance to acetolactate synthase- and acetyl coenzyme A carboxylase-inhibitor herbicides (Heap 2012). After the queries were executed, we used the "analyze results" feature in Scopus to obtain details on query results (publication source, author affiliations, country, and article type).

For our analysis, the vast majority of all publications we considered were scientific papers in refereed journals. For
Table 1. The top five weed biology ${ }^{a}$ article sources and numbers from 1995 to June 1, 2012 (Scopus query). Total articles published $=10,705$.

\begin{tabular}{llr}
\hline Source & \multicolumn{1}{c}{ Name } & $\#$ \\
\hline Journal & Weed Science & 832 \\
& Weed Technology & 473 \\
& Weed Research & 429 \\
& Allelopathy Journal & 205 \\
Affiliation & Crop Protection $^{\mathrm{d}}$ & 204 \\
& USDA ARS $^{\mathrm{b}}$ & 409 \\
& University of Florida & 194 \\
& University of California Davis $^{\text {AAFC }}$ & 172 \\
Country & North Carolina State University & 154 \\
& United States & 136 \\
& Australia & 3,399 \\
& Canada & 977 \\
& United Kingdom & 685 \\
& India & 647 \\
\end{tabular}

${ }^{\text {a }}$ Scopus query (June 1, 2012): "TITLE-ABS-KEY(weed* AND (biology OR ecology OR allelo* OR competition OR interference OR "critical period" OR duration OR population OR "spatial distribution) AND PUBYEAR > 1994".

${ }^{\mathrm{b}}$ United States Department of Agriculture-Agricultural Research Service.

${ }^{\mathrm{c}}$ Agriculture and Agri-Food Canada.

example, for the queries involving just "weed control," "weed management," and "IWM" articles, 84\% were scientific articles $(11,490)$, 9\% were conference proceedings $(1,259)$, and $5 \%$ were reviews (694). The remaining publications (2\%) included short surveys, notes, articles in press, undefined contributions, books, etc.

\section{Results and Discussion}

Weed Biology. As mentioned above, knowledge of weed biology and ecology is essential to the development of successful IWM systems. Since 1994, Weed Science has published more weed biology and ecology articles than any other scientific publication source (Table 1). U.S. Department of Agriculture-Agricultural Research Service (USDA-ARS) authors published more than twice the weed biology articles than authors from any other research affiliation. Authors from the United States (all affiliations), Australia, Canada, the United Kingdom, and India all published a substantial number of weed biology articles (top five author-affiliated countries).

Weed Detection. Weed detection technology provides essential "scouting" information in many weed management systems. Publishing sources and affiliations for this subject area include a wider variety of participants than any other research area in the review (Table 2). Typical weed journals rank third (Weed Technology) and fifth (Weed Research) in this area. Although United States authors published the most weed detection articles, authors from China were also significant contributors.

Preventative Weed Management. Preventative weed management is a key strategy in IWM systems (Hamill et al. 2004); it is the first and probably most important consideration for new weed populations, particularly invasive species. Maxwell and O'Donovan (2007) suggested that a first principle of nonchemical weed management could be that the 
Table 2. The top five weed detection ${ }^{\text {a }}$ article sources and numbers from 1995 to June 1, 2012 (Scopus query). Total articles published $=479$.

\begin{tabular}{llr}
\hline Source & \multicolumn{1}{c}{ Name } & $\#$ \\
\hline Journal & Computers and Electronics in Agriculture & 31 \\
& Proceedings of SPIE the International Society for Optical & 28 \\
& Engineering & \\
& Transactions of the American Society of Agricultural & 17 \\
& Engineers & \\
& Weed Technology & 14 \\
& Nongye Jixie Xuebao Transactions of the Chinese Society of & 13 \\
& Agric. Machinery & 13 \\
& Weed Research & 18 \\
Affiliation & University of Illinois & 18 \\
& Wageningen University and Research Centre & 14 \\
& University of California Davis & 12 \\
& Silsoe Research Institute & 10 \\
& Universidad Complutense de Madrid & 10 \\
& Consejo Superior de Investigaciones Cientificas & 10 \\
& Iowa State University & 130 \\
& University of Florida & 54 \\
& University of Nebraska - Lincoln & 28 \\
Country & United States & 28 \\
& China & 27 \\
& Canada & 26 \\
& Germany & \\
& Spain & \\
& Japan & \\
& United Kingdom
\end{tabular}

a Scopus query (June 1, 2012): "TITLE-ABS-KEY ("weed detect*" OR (weed AND (vision OR sense OR robot*))) AND PUBYEAR > 1994".

higher the uncertainty in a crop-weed interaction, the more management emphasis should be placed on prevention and less on causing weed mortality. Since 1994, Weed Technology, Weed Science, and Weed Research all contributed at least 60 preventative weed management articles (Table 3). Given the fact that Invasive Plant Science and Management was first published in January 2008, it is impressive that 20 preventative weed management articles have now been published in that journal. Authors from the USDA-ARS contributed the most articles in this category (44), whereas authors from Wageningen University and Research Centre published 30 articles. Although U.S. authors published the most preventative weed management articles (390), Australian authors published almost one-third of that number (121). Considering much lower arable land levels and agricultural scientist numbers in Australia vs. the United States, relatively early and severe weed resistance issues have likely led to relatively greater awareness, research interest, and publishing efforts related to preventative weed management strategies in Australia.

Weed Control vs. IWM. Thill et al. (1991) noted that weed scientists may have responded positively to Shaw's (1982) request for more IWM research made during the 1981 Weed Science Society of America IWM Symposium. They observed that before the Symposium, from 1960 to 1981, "about 4\% of all Weed Science articles dealt with IWM" and that from 1982 to 1989 "about $8 \%$ of the articles of the articles published in Weed Science have dealt with IWM" (Thill et al. 1991). However, Thill et al. (1991) noted that the IWM publishing trend from 1982 to 1989 was a definite regression. Apparently, the plea for more IWM research was either
Table 3. The top five preventative weed management ${ }^{\mathrm{a}}$ article sources and numbers from 1995 to June 1, 2012 (Scopus query). Total articles published $=$ 1,270 .

\begin{tabular}{llr}
\hline Source & \multicolumn{1}{c}{ Name } & $\#$ \\
\hline Journal & Weed Technology & 78 \\
& Weed Research & 60 \\
& Weed Science & 60 \\
& Crop Protection & 33 \\
& Planta Daninha & 32 \\
& Invasive Plant Science and Management & 20 \\
Affiliation & USDA ARS & 44 \\
& Wageningen University and Research Centre & 30 \\
& University of Florida & 23 \\
& University of Western Australia & 23 \\
& UNESP-Universidade Estadual Paulista & 21 \\
& University of California Davis & 20 \\
Country & United States & 390 \\
& Australia & 121 \\
& United Kingdom & 71 \\
& Brazil & 62 \\
& Canada & 61 \\
& &
\end{tabular}

${ }^{a}$ Scopus query (June 1, 2012): "TITLE-ABS-KEY(prevent* AND (weed* OR "weed control" OR "weed management")) AND PUBYEAR > 1994".

${ }^{\mathrm{b}}$ United States Department of Agriculture-Agricultural Research Service.

reconsidered or quickly forgotten. More than $20 \mathrm{yr}$ later, depending on one's perspective, things may or may not have improved. Although there is a slight but consistent upward trend in published "IWM" articles in the Scopus database, the upward trend in "weed control" articles is much stronger (Figure 2). Furthermore, during the 17-yr period from 1995 to 2011, "weed control" articles outnumbered "IWM" articles by a ratio of 14 to $1(10,359$ to 720$)$.

One purpose for our simple queries of "weed control" and "weed management" (Figure 2) was to determine if weed scientists were shifting their thinking in terms of how weeds should be managed. If IWM is to become more widely implemented in research programs as well as on the farm, replacing a weed control mentality with a weed management mentality will be necessary.

The evolution of strategies from weed control to weed management to IWM in research publications suggests a necessary shift in research emphasis toward more sustainable weed management techniques. Nevertheless, weed control articles from the last 17 years outnumbered weed management articles by a ratio of almost 4 to $1(9,964$ to 2,708$)$ (Figure 2). During the same time period weed management articles outnumbered "integrated weed management" articles by a similar 4 -to-1 ratio (2,708 to 697). However, titles, abstracts, and key words do not always tell the full story. For example, in 1987, two weed papers were published, with one mentioning "management" (Bridges and Walker 1987) and the other mentioning "control" (Cardina et al. 1987); both papers were excellent examples of real IWM.

Journals Publishing Weed Management Method Articles. Given its mandate to determine "how" weeds are managed, Weed Technology publishes more weed management method papers than any other scientific journal (Table 4). The only weed management category where Weed Technology falls behind some other journals is biological control. In the latter category, Biocontrol Science and Technology, Biological Control, 


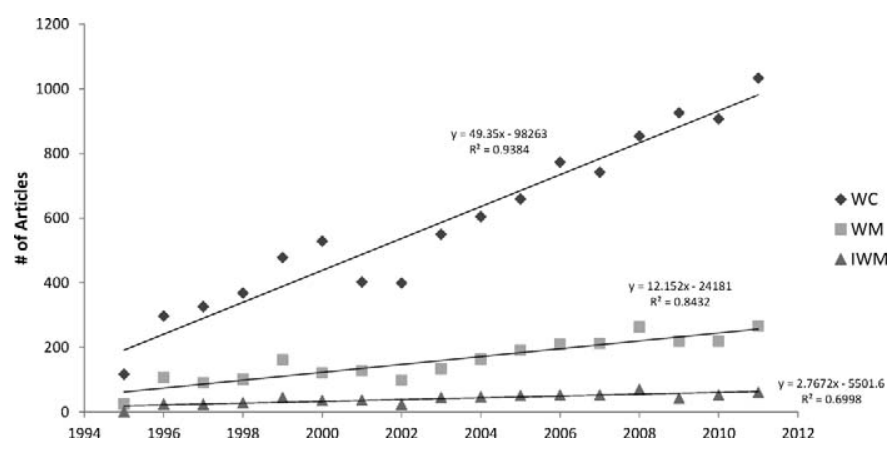

Figure 2. Weed research articles published with "weed control" (WC), "weed management" (WM), or "integrated weed management" (IWM) listed in the title, abstract, or key words from 1995 to 2011 (Scopus query). Total articles published in the specified time period were 9,964, 2,708, and 697 for WC, WM, and IWM, respectively.

and Weed Science all publish more articles than Weed Technology.

Author Affiliations Publishing Weed Management Method Articles. USDA ARS authors published the most weed management articles and led all other affiliations in five of six weed management categories (Table 5). Agriculture and AgriFood Canada authors led other affiliations in publishing cultural weed management articles. Wageningen University and Research Centre, University of Florida, Commonwealth Scientific and Industrial Research Organisation Entomology, North Carolina State University, and Michigan State University authors were also among the top three affiliations publishing weed management method articles.

Countries Publishing Weed Management Method Articles. U.S. authors published the most weed management articles and led all other countries in all six weed management categories (Table 6). The number of weed scientists in the United States is probably greater than in any other country. Authors from Canada, India, Australia, and the United Kingdom were also among the top three countries with authors publishing weed management method articles.

Proportional IWM Publishing on the Basis of Population, Arable Land, and Crop Production. Country comparisons were more interesting, and perhaps more fairly compared, when articles published were on the basis of country population, arable land, and crop production (Table 7). In the article-population chart (Figure 3), the number of published IWM articles from the top 10 countries is expressed as a percentage of country population $\left(\# 1,000,000^{-1}\right)$. The top three countries with authors publishing IWM articles on the basis of population proportion were Australia, Canada, and New Zealand. In the article arable land chart (Figure 4), the number of published IWM articles from the top 10 countries is expressed as a percentage of country arable land $\left(\mathrm{km}^{2} 1,000^{-1}\right)$. The top three countries with authors publishing IWM articles on the basis of arable land proportion were Switzerland, the Netherlands, and New Zealand. In the article crop production chart (Figure 5), the number of published IWM articles from the top 10 countries is expressed as a percentage of country crop production ( $\mathrm{Mt}$
Table 4. Article numbers in the top five journals publishing weed management methods from 1995 to June 1, 2012 (Scopus query). ${ }^{a}$

\begin{tabular}{|c|c|c|}
\hline Rank & Method & $\#$ \\
\hline \multicolumn{3}{|c|}{ Preventative } \\
\hline 1 & Weed Technology & 78 \\
\hline 2 & Weed Research & 60 \\
\hline 2 & Weed Science & 60 \\
\hline 3 & Crop Protection & 33 \\
\hline 4 & Planta Daninha & 32 \\
\hline 5 & Invasive Plant Science and Management & 20 \\
\hline \multicolumn{3}{|c|}{ Biological control } \\
\hline 1 & Biocontrol Science and Technology & 128 \\
\hline 2 & Biological Control & 101 \\
\hline 3 & Weed Science & 87 \\
\hline 4 & Weed Technology & 68 \\
\hline 5 & Biocontrol & 65 \\
\hline \multicolumn{3}{|c|}{ Chemical control } \\
\hline 1 & Weed Technology & 937 \\
\hline 2 & Weed Science & 421 \\
\hline 3 & Crop Protection & 281 \\
\hline 4 & Weed Research & 223 \\
\hline 5 & Pest Management Science & 175 \\
\hline \multicolumn{3}{|c|}{ Cultural control } \\
\hline 1 & Weed Technology & 224 \\
\hline 2 & Weed Science & 213 \\
\hline 3 & Weed Research & 111 \\
\hline 4 & Crop Protection & 100 \\
\hline 5 & Indian Journal of Agricultural Sciences & 81 \\
\hline \multicolumn{3}{|c|}{ Physical control } \\
\hline 1 & Weed Technology & 297 \\
\hline 2 & Weed Science & 241 \\
\hline 3 & Weed Research & 146 \\
\hline 4 & Crop Protection & 117 \\
\hline 5 & Agronomy Journal & 80 \\
\hline \multicolumn{3}{|c|}{ Alternative } \\
\hline 1 & Weed Technology & 223 \\
\hline 2 & Weed Science & 154 \\
\hline 3 & Weed Research & 96 \\
\hline 4 & Crop Protection & 93 \\
\hline 5 & Agronomy Journal & 53 \\
\hline
\end{tabular}

${ }^{a}$ Refer to Materials and Methods section for individual queries (bottom six queries) on each weed management method (method key word in bold font).

$\left.1,000,000^{-1}\right)$. The top three countries with authors publishing IWM articles on the basis of crop production proportion were New Zealand, Switzerland, and Canada. Therefore, although U.S. authors have published more IWM articles than authors from any other country, when IWM article numbers were weighted as a proportion of country population, arable land, or crop production, authors from New Zealand, Canada, Switzerland, Australia, and the Netherlands were most prominent.

IWM Components and Combinations. Given the rather low number of IWM articles vs. weed control articles shown in Figure 2, it is encouraging to observe the steady increase in nonchemical articles published since 1994 (Figure 6). Clearly, the knowledge required for the discovery of new IWM components and the study of the components themselves has been substantially augmented. Nonchemical articles provide knowledge regarding IWM components that have been somewhat neglected in the past (Altieri and Liebman 1988; 
Table 5. Article numbers for the top five affiliations publishing weed management methods from 1995 to June 1, 2012 (Scopus query). ${ }^{\text {}}$

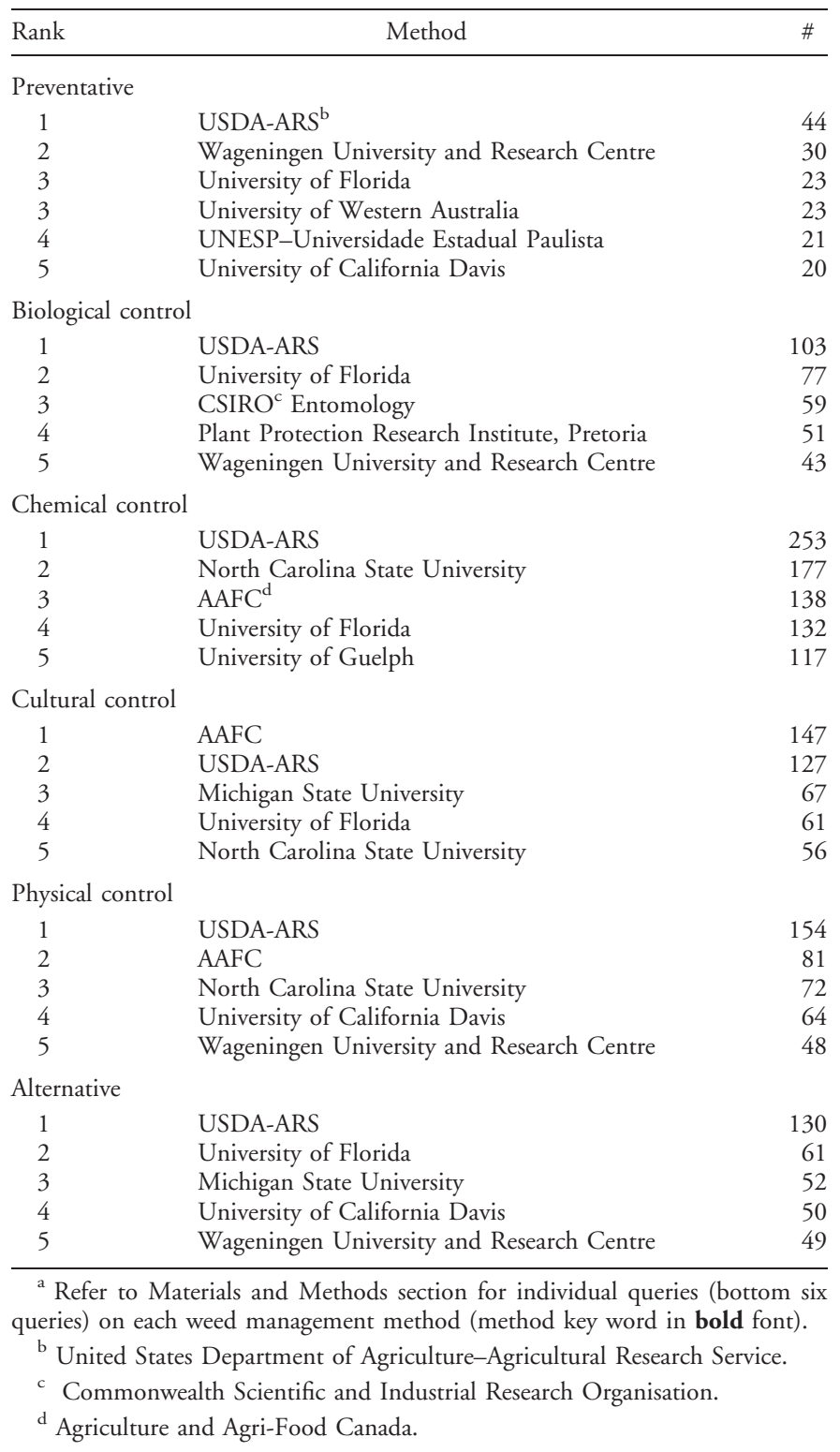

Buhler 1999; Roush et al. 1990; Thill et al. 1991; Wyse 1992). In addition, that nonchemical weed management articles were published at a more rapid pace than HR weed biotypes are confirmed is encouraging, if the idea for such a comparison was not so menacing (Figure 6). Encouragement, however, should be tempered by the fact that some articles were counted in more than one subject area (i.e., total articles numbers were lower). Nevertheless, observing the rate that nonchemical weed management and IWM system articles are published in the future will be interesting.

Some argue that nonchemical and other alternative weed management strategies are not sufficiently efficacious or economical. Although current tools may not be highly effective for growers right now, researchers should not abandon their quest for future weed management alternatives. Furthermore, given the rapid expansion of HR weed
Table 6. Article numbers for the top five countries publishing weed management methods from 1995 to June 1, 2012 (Scopus query). ${ }^{\text {}}$

\begin{tabular}{|c|c|c|}
\hline Rank & Method & $\#$ \\
\hline \multicolumn{3}{|c|}{ Preventative } \\
\hline 1 & United States & 390 \\
\hline 2 & Australia & 121 \\
\hline 3 & United Kingdom & 71 \\
\hline 4 & Brazil & 62 \\
\hline 5 & Canada & 61 \\
\hline \multicolumn{3}{|c|}{ Biological control } \\
\hline 1 & United States & 647 \\
\hline 2 & Australia & 233 \\
\hline 3 & Canada & 145 \\
\hline 4 & United Kingdom & 105 \\
\hline 5 & South Africa & 95 \\
\hline \multicolumn{3}{|c|}{ Chemical control } \\
\hline 1 & United States & 2,347 \\
\hline 2 & Canada & 512 \\
\hline 3 & India & 466 \\
\hline 4 & Australia & 323 \\
\hline 5 & Brazil & 294 \\
\hline \multicolumn{3}{|c|}{ Cultural control } \\
\hline 1 & United States & 874 \\
\hline 2 & India & 260 \\
\hline 3 & Canada & 257 \\
\hline 4 & Australia & 157 \\
\hline 5 & Brazil & 110 \\
\hline \multicolumn{3}{|c|}{ Physical control } \\
\hline 1 & United States & 1,065 \\
\hline 2 & India & 241 \\
\hline 3 & Canada & 227 \\
\hline 4 & Brazil & 173 \\
\hline 5 & Germany & 147 \\
\hline \multicolumn{3}{|c|}{ Alternative } \\
\hline 1 & United States & 866 \\
\hline 2 & Canada & 180 \\
\hline 3 & India & 139 \\
\hline 4 & Australia & 135 \\
\hline 5 & Spain & 109 \\
\hline
\end{tabular}

${ }^{a}$ Refer to Materials and Methods section for individual queries (bottom six queries) on each weed management method (method key word in bold font).

populations, the economic feasibility of alternative weed management strategies may substantially improve in the near future. Thomas et al. (2010) concluded that cultural weed management practices can both complement and substitute for herbicides. Forward-thinking researchers ignore some "low efficacy" and "low profit" comments by farmers and other researchers to develop new weed management techniques that will contribute future "little hammers" for weeds (Liebman and Gallandt 1997). "Weed scientists who want to change things" face a difficult task (Zimdahl 1994).

Many researchers have answered the challenge to develop true IWM systems that include more than one method of weed management (Buhler 1999; Swanton and Weise 1991) and to raise the profile of nonchemical weed management research. The principle of using "many little hammers" to manage crop-weed interactions (Liebman and Gallandt 1997) also appears to be gaining more momentum. Weed management tools such air-propelled corn grit (Forcella 2012), weed-suppressing Brassica seed meal (Handiseni et al. 2011), cryogenic salts (Jitsuyama and Ichikawa 2011), early- 
Table 7. Population, arable land, and crop production (total of top five crops) data for the top 10 countries publishing "integrated weed management" articles (listed in the title, abstract, or key words) from 1995 to June 1, 2012 (Scopus query).

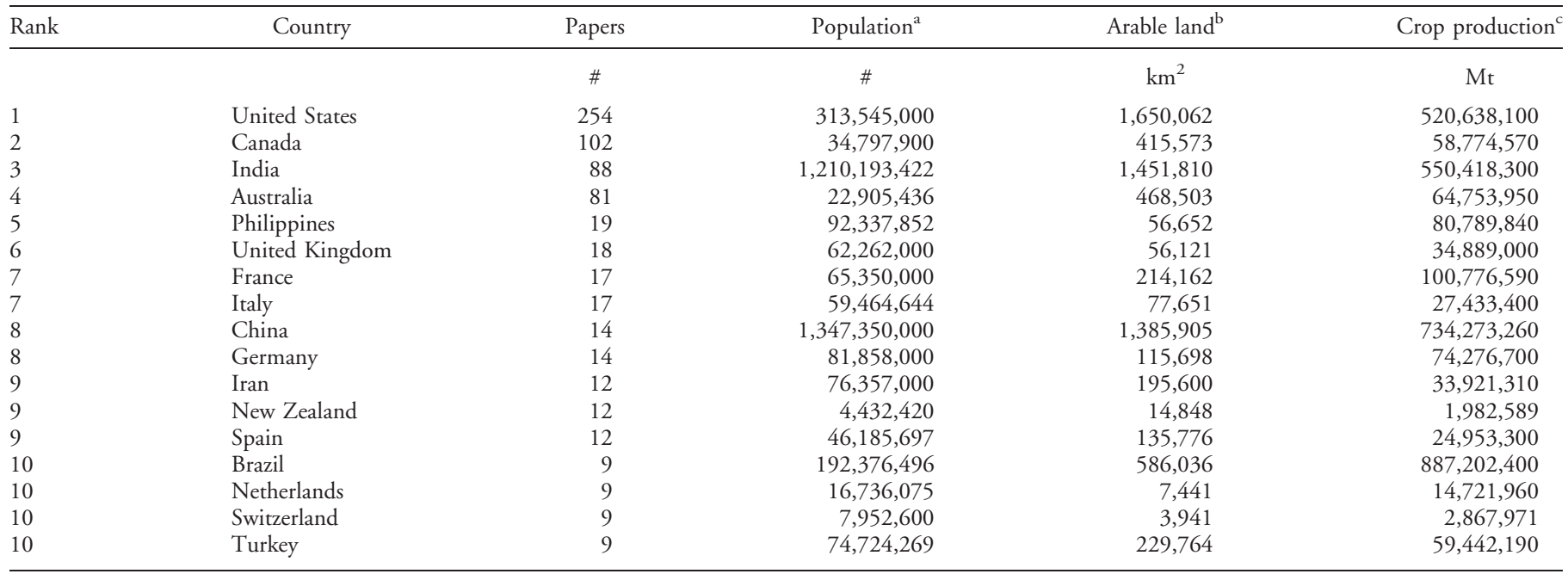

${ }^{a}$ Source: http://en.wikipedia.org/wiki/List_of_countries_by_population\#List.

b Source: http://en.wikipedia.org/wiki/Land_use_statistics_by_country.

c Source: http://faostat.fao.org/site/339/default.aspx.

cut barley silage (Harker et al. 2003b), crop rotation (Liebman and Dyck 1993), chaff and weed seed collection (Shirtliffe and Entz 2005), the Harrington seed destructor (Walsh et al. 2012), higher crop seeding rates (O'Donovan et al. 2006), sized crop seed (Xue and Stougaard 2006), robotic weeders (Blasco et al. 2002), band-steaming (Melander et al. 2002), planting patterns (Mahajan and Chauhan 2011), competitive species (Beres et al. 2010), competitive cultivars (Drew et al. 2009), intercropping (Nelson et al. 2012), and some of the many techniques developed in Australia against GR rigid ryegrass (Lolium rigidum Gaudin) (Llewellyn et al. 2004) can be among the useful tools used together in global IWM systems.

Not all IWM tools are new techniques. The relatively recent focus on herbicidal weed control and HR crops effectively caused us to forget many historically effective nonchemical weed management techniques. A paper on

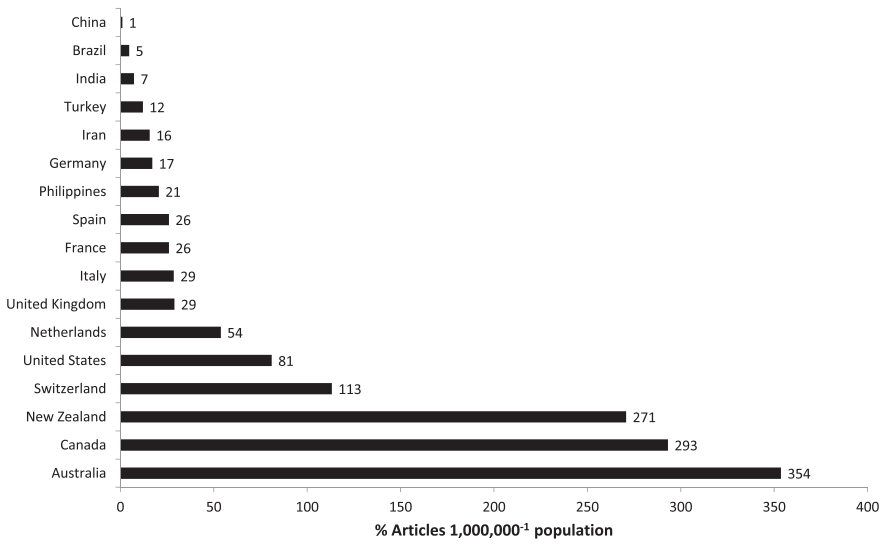

Figure 3. Top 10 countries with authors publishing "integrated weed management" papers as a percentage of country population $\left(1,000,000^{-1}\right)($ see Table 7). suppressing weeds with higher crop seeding rates was published in 1935 (Godel 1935), and crop rotation has been advocated for centuries to manage weeds. However, novelty and innovation occur when these tools are combined with other tools in modern cropping systems. There are numerous examples showing the benefit of combining multiple tools in IWM systems (Anderson 2000, 2003, 2005, Barton et al. 1992; Blackshaw et al. 1999, 2005, 2008; Harker et al. 2003a, 2009; Holm et al. 2006; Kolb et al. 2012; Melander et al. 2005; O'Donovan et al. 2007; Wang et al. 2012; Westerman et al. 2005; Young et al. 2010). For example, Anderson (2000) showed that, in the absence of herbicides, combining high seeding rates with seed-banded nitrogen fertilizer and a tall proso millet (Panicum miliaceum L.) cultivar eliminated crop yield loss due to weeds.

Perhaps the most rapid discovery, reinvention, and adoption of alternatives to herbicides in modern agricultural

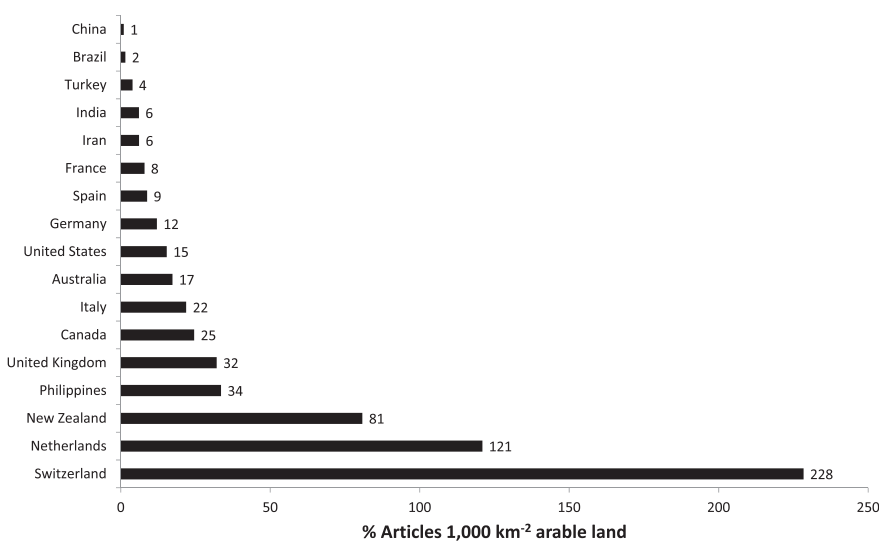

Figure 4. Top 10 countries with authors publishing "integrated weed management" papers as a percentage of country arable land $\left(1,000 \mathrm{~km}^{-2}\right)$ (see Table 7). 


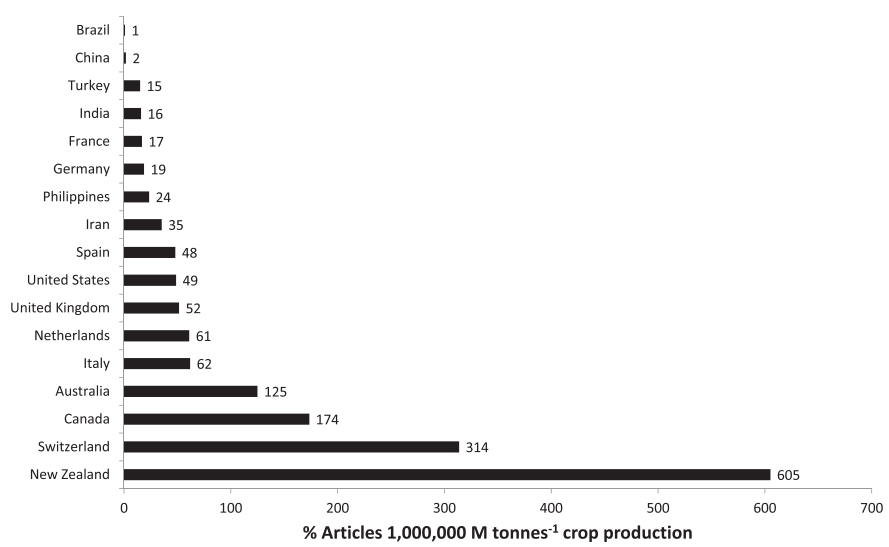

Figure 5. Top 10 countries with authors publishing "integrated weed management" papers as a percentage of country crop production $(1,000,000$ $\mathrm{Mt}^{-1}$ ) (see Table 7).

cropping systems has been in Australia where multipleresistant rigid ryegrass has forced growers and researchers to look for herbicide alternatives. Llewellyn et al. (2004) list 18 nonherbicidal IWM practices that have been relatively recently used by Western Australian grain growers to reduce rigid ryegrass populations. Similar innovation and IWM research are likely to occur in the immediate future where glyphosate-resistant weeds are beginning to dominate some cropping regions. As Beckie (2006) suggests, increased grower adoption of IWM techniques usually only occurs after HR weeds have been confirmed on their farm. Therefore, one might expect a resurgence in IWM technique development and grower adoption of those techniques in southeastern United States cotton (Gossypium hirsutum L.)-growing regions where Palmer amaranth (Amaranthus palmeri S. Wats.), the major weed in cotton, is now resistant to glyphosate (Culpepper et al. 2006; Norsworthy et al. 2008; Steckel et al. 2008) and to herbicides with other mechanisms of action (Heap 2012).

Although new weed management method and IWM component combination papers are needed much more than yet another herbicide efficacy paper, new management method and IWM papers usually require more time, resources, and innovation to develop and publish. Comparatively, herbicide efficacy papers can be relatively easy to publish and offer a quick pathway to career success. However, discovering and utilizing weed management practices in addition to herbicides is essential to achieve true IWM and preserve the efficacy of valuable herbicide tools (Beckie 2006, 2007; Buhler 1999; Duke 2011; Hamill et al. 2004; Powles and Yu 2010).

Research funding opportunities often determine research direction. Weed scientists are not solely responsible for the promotion and adoption of IWM techniques and systems. The search for new weed management techniques and answers to basic weed biology and ecology questions leading to successful IWM systems (Harker et al. 2012; Radosevich and Ghersa 1992; Swanton et al. 2008; Thill et al. 1991; Wyse 1992; Zimdahl 1994) requires visionary and long-term research funding by multinationals, grower-funded organiza-

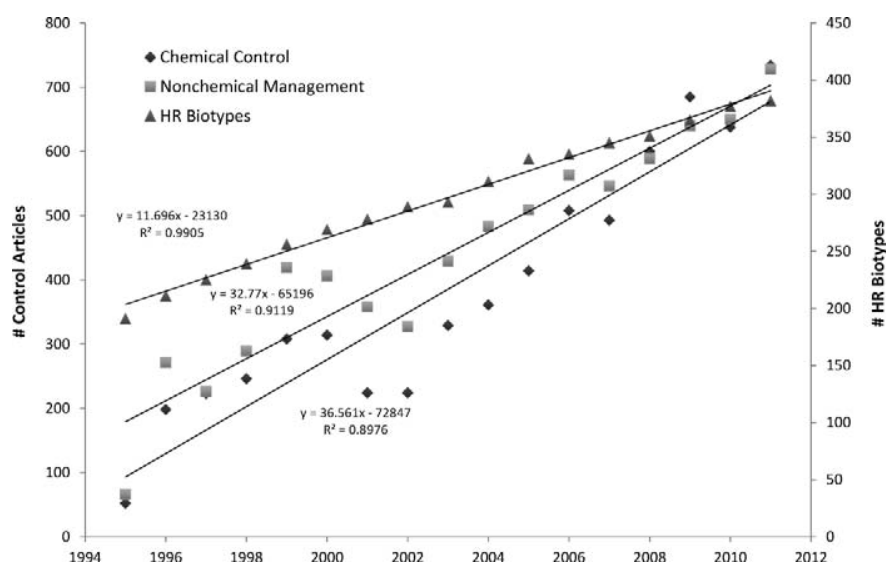

Figure 6. Chemical control and nonchemical (biological, cultural, and physical combined) weed management articles published from 1995 to 2011 (Scopus queries). The numbers of herbicide-resistant (HR) weed biotypes confirmed over the same time period are also illustrated (Heap 2012).

tions, and various levels of government. Complex, systembased research programs require many years of study that can be less amenable to short-term funding priorities as well as scientific career advancement. Perhaps a shift in how researchers are evaluated would advance IWM research as much as anything.

The publication record reviewed here suggests that some weed scientists are shifting more emphasis to weed biology and ecology, as well as developing weed management tools other than herbicides (Figure 6). Swanton and Murphy (1996) suggest that IWM research needs to focus on indicators of agroecosystem health to help determine longterm consequences and constraints of IWM adoption. We hope this article will stimulate new avenues of IWM research and reduce the 14-to-1 ratio of published weed control to IWM articles.

Finally, greater grower adoption of IWM practices would likely stimulate research funding and increase interest levels among weed researchers. However, growers, consultants, and industry representatives like relatively quick prescriptive solutions for weed problems with low uncertainty. The certainty associated with recommending a highly efficacious herbicide or herbicide mixture is likely to be greater than that associated with nonchemical management recommendations, at least in the short term (Maxwell and O'Donovan 2007). The key to generating more interest and innovation in IWM research may lie in educating growers and industry on the long-term benefits of more holistic principles of weed management rather than relying solely on more rapid prescriptive solutions. Nonmarket-based programs that attempt to internalize environmental externalities such as the U.S. Environmental Quality Incentives Program may also help to increase IWM funding, research, and grower adoption.

Research Implications. If nothing else, this article may provide impetus for researchers to include adequate key words in titles, abstracts, and key word sections of their manuscripts to ensure that their work is fully credited and discovered. This 
article is somewhat biased toward those that were careful to add appropriate key words to their articles. It is also likely that some articles purporting to be about IWM are really only integrated herbicide management (Harker et al. 2012) similar to the "other IPM" (Ehler 2006), and therefore should not be included as IWM articles. Nevertheless, if IWM-related key words are not mentioned in titles, abstracts, or key words, they are probably not important to the research or the article.

Much progress developing alternative weed management techniques, and the integration of these and other techniques into real IWM systems, has been made. Some organizations and countries have been more successful than others. Nevertheless, there is still much more that can and should be done. More IWM-focused priorities, increased IWM funding levels from various agencies, and greater grower education as to the long-term benefits of IWM could facilitate crucial changes in research direction. Wyse's lament 20 years ago (1992) that: "a large portion of the resources devoted to weed science have been devoted to herbicide research" may be outdated; perhaps many weed scientists have listened and responded. But a continued overemphasis on chemical weed control by many weed scientists will continue to retard "the development of weed science as a balanced discipline" (Wyse 1992).

Current and future weed scientists will determine whether weed science will continue to be perceived as a discipline that studies only herbicides. Hamill et al. (2004) suggest that weed science has shifted from an early emphasis on herbicides to a more complete integration of several control methods that are determined on ecological as well as economic goals. The potential promise that real IWM brings to agricultural sustainability is dependent upon a continued focus on weed biology, weed ecology, developing new management tactics, and studying and implementing diverse combinations of IWM systems.

\section{Literature Cited}

Altieri, M. A. and M. Liebman. 1988. Weed management in agroecosystems: Ecological approaches. Boca Raton, FL: CRC Press. 354 p.

Anderson, R. L. 2000. A cultural system approach can eliminate herbicide need in semiarid proso milet (Panicum miliaceum). Weed Technol. 14:602-607.

Anderson, R. L. 2003. An ecological approach to strengthen weed management in the semiarid Great Plains. Adv. Agron. 80:33-62.

Anderson, R. L. 2005. A multi-tactic approach to manage weed population dynamics in crop rotations. Agron. J. 97:1579-1583.

Barton, D. L., D. C. Thill, and B. Shafi. 1992. Integrated wild oat (Avena fatua) management affects spring barley (Hordeum vulgare) yield and economics. Weed Technol. 6:129-135.

Barrett, S.C.H. 1983. Crop mimicry in weeds. Econ. Bot. 37:255-282.

Beckie, H. J. 2006. Herbicide-resistant weeds: management tactics and practices. Weed Technol. 20:793-814.

Beckie, H. J. 2007. Beneficial management practices to combat herbicide-resistant grass weeds in the Northern Great Plains. Weed Technol. 21:290-299.

Beres, B. L., K. N. Harker, G. W. Clayton, E. Bremer, R. E. Blackshaw, and R. J. Graf. 2010. Weed competitive ability of spring and winter cereals in the Northern Great Plains. Weed Technol. 24:108-116.

Blackshaw, R. E., K. N. Harker, J. T. O’Donovan, H. J. Beckie, and E. G. Smith. 2008. Ongoing development of integrated weed management systems on the Canadian Prairies. Weed Sci. 56:146-50.

Blackshaw, R. E., J. R. Moyer, K. N. Harker, and G. W. Clayton. 2005. Integration of agronomic practices and herbicides for sustainable weed management in a zero-till barley field pea rotation. Weed Technol. 19:190196.
Blackshaw, R. E., G. Semach, X. Li, J. T. O’Donovan, and K. N. Harker. 1999. An integrated weed management approach to managing foxtail barley (Hordeum jubatum) in conservation tillage systems. Weed Technol. 13:347353.

Blasco, L., N. Aleixos, J. M. Roger, G. Rabatel, and E. Molto. 2002. Robotic weed control using machine vision. Biosyst. Eng. 83:149-157.

Bridges, D. C. and R. H. Walker. 1987. Economics of sicklepod (Cassia obtusifolia) management. Weed Sci. 35:594-598.

Buhler, D. D. 1996. Development of alternative weed management strategies. J. Prod. Agric. 9:501-505.

Buhler, D. D. 1999. Expanding the context of weed management. J. Crop Prod. $2: 1-7$.

Cardina, J., A. C. Mixon, and G. R. Wehtje. 1987. Low cost weed control systems for close-row peanuts (Arachis hypogaea). Weed Sci. 35:700-703.

Culpepper, A. S., T. L. Grey, W. K. Vencill, J. M. Kichler, T. M. Webster, S. M. Brown, A. C. York, J. W. Davis, and W. W. Hanna. 2006. Glyphosateresistant Palmer amaranth (Amaranthus palmeri) confirmed in Georgia. Weed Sci. 54:620-626.

Drew, S., D. Neuhoff, and U. Köpke. 2009. Weed suppression ability of three winter wheat varieties at different row spacing under organic farming conditions. Weed Res. 49:526-33.

Duke, S. O. 2005. Taking stock of herbicide-resistant crops ten years after introduction. Pest Manag. Sci. 61:211-218.

Duke, S. O. 2011. Comparing conventional and biotechnology-based pest management. J. Agric. Food Chem. 59:5793-5798.

Egan, J. F., B. D. Maxwell, D. A. Mortensen, M. R. Ryan, and R. G. Smith. 2011. 2, 4-dichlorophenoxyacetic acid (2, 4-D)-resistant Q:1 crops and the potential for evolution of 2, 4-D-resistant weeds. Proc. Natl. Acad. Sci. USA 108 E37; published ahead of print March 3, 2011, DOI: 10.1073/pnas. 1017414108.

Ehler, L. E. 2006. Integrated pest management (IPM): definition, historical development and implementation, and the other IPM. Pest Manag. Sci. 62:787-789.

Forcella, F. 2012. Air-propelled abrasive grit for postemergence in-row weed control in field corn. Weed Technol. 26:161-164.

Godel, G. L. 1935. Relations between rate of seeding and yield of cereal crops in competition with weeds. Sci. Agr. 16:165-168.

Hamill, A. S., J. S. Holt, and C. A. Mallory-Smith. 2004. Contributions of weed science to weed control and management. Weed Technol. 18:1563-1565.

Handiseni, M., J. Brown, R. Zemetra, and M. Mazzola. 2011. Herbicidal activity of Brassicaceae seed meal on wild oat (Avena fatua), Italian ryegrass (Lolium multiflorum), redroot pigweed (Amaranthus retroflexus), and prickly lettuce (Lactuca serriola). Weed Technol. 25:127-134.

Harker, K. N. 2004. My view. Weed Sci. 52:183-184

Harker, K. N., G. W. Clayton, R. E. Blackshaw, J. T. O’Donovan, and F. C. Stevenson. 2003a. Seeding rate, herbicide timing and competitive hybrids contribute to integrated weed management in canola (Brassica napus). Can. J. Plant Sci. 83:433-440.

Harker, K. N., K. J. Kirkland, V. S. Baron, and G. W. Clayton. 2003b. Earlyharvest barley (Hordeum vulgare) silage reduces wild oat (Avena fatua) densities under zero tillage. Weed Technol. 17:102-110.

Harker, K. N., J. T. O’Donovan, R. E. Blackshaw, H. J. Beckie, C. MallorySmith, and B. D. Maxwell. 2012. Our view. Weed Sci. 60:143-144.

Harker, K. N., J. T. O’Donovan, R. B. Irvine, T. K. Turkington, and G. W. Clayton. 2009. Integrating cropping systems with cultural techniques augments wild oat (Avena fatua) management in barley (Hordeum vulgare). Weed Sci. 57:326-337.

Heap, I. 2012. International survey of herbicide resistant weeds. URL available: http://www.weedscience.org/In.asp. Accessed: May 23, 2012.

Holm, F. A., R. P. Zentner, A. G. Thomas, K. Sapsford, A. Légère, B. D. Gossen, O. Olfert, and J. Y. Leeson. 2006. Agronomic and economic responses to integrated weed management systems and fungicide in a wheat-canola-barleypea rotation. Can J. Plant Sci. 86:1281-1295.

Holt, J. S. 1994. Impact of weed control on weeds: new problems and research needs. Weed Technol. 8:400-402.

Jitsuyama, Y. and S. Ichikawa. 2011. Possible weed establishment control by applying cryogens to fields before snowfalls. Weed Technol. 25:454-458.

Kolb, L. N., E. R. Gallandt, and E. B. Mallory. 2012. Impact of spring wheat planting density, row spacing, and mechanical weed control on yield, grain protein, and economic return in Maine. Weed Sci. 60:244-253.

Liebman, M. and E. Dyck. 1993. Crop rotation strategies for weed management. Ecol. Applic. 3:92-122. 
Liebman, M. and E. R. Gallandt. 1997. Many little hammers: ecological management of crop-weed interactions. Pages 291-343 in L. E. Jackson, ed. Ecology in Agriculture. San Diego, CA: Academic.

Liebman, M., C. L. Mohler, and C. P. Staver. 2001. Ecological management of agricultural weeds. Cambridge, UK: Cambridge University Press. 532 p.

Llewellyn, R. S., R. K. Lindner, D. J. Pannell, and S. B. Powles. 2004. Grain grower perceptions and use of integrated weed management. Aust. J. Exp. Agric. 44:993-1001.

Mahajan, G. and B. S. Chauhan. 2011. Effects of planting pattern and cultivar on weed and crop growth in aerobic rice system. Weed Technol. 25:521-525.

Maxwell, B. D. and E. Luschei. 2004. The ecology of crop-weed interactions: towards a more complete model of weed communities in agroecosystems. J. Crop Improv. 11:137-151.

Maxwell, B. D. and J. T. O’Donovan. 2007. Understanding weed-crop interactions to manage weed problems. Pages 17-33 in M. K. Upadhyaya and R. R. Blackshaw, eds. Nonchemical Weed Management: Principles, Concepts and Technology. Oxfordshire, UK: CAB International.

Melander, B., T. Heisel, and M. H. Jrgensen. 2002. Aspects of steaming the soil to reduce weed seedling emergence. Pages 236-237 in Proceedings of the 12th EWRS Symposium. Wageningen, Papendal, the Netherlands: European Weed Research Society.

Melander, B., I. A. Rasmussen, and P. Bàrberi. 2005. Integrating physical and cultural methods of weed control—examples from European research. Weed Sci. 53:369-381.

Mortensen, D. A., L. Bastiaans, and M. Sattin. 2000. The role of ecology in the development of weed management systems: an outlook. Weed Res. 40:49-62.

Navas, M. L. 1991. Using plant population biology in weed research: a strategy to improve weed management. Weed Res. 31:171-179.

Nelson, A. G., A. Pswarayi, S. Quideau, B. Frick, and D. Spaner. 2012. Yield and weed suppression of crop mixtures in organic and conventional systems of the western Canadian prairie. Agron. J. 104:756-762.

Norsworthy, J. K., G. M. Griffith, R. C. Scott, K. L. Smith, and L. R. Oliver. 2008. Confirmation and control of glyphosate-resistant Palmer amaranth (Amaranthus palmeri) in Arkansas. Weed Technol. 22:108-113.

[NRC] National Research Council. Proceedings of a conference on the destruction of weeds by means of chemicals. Oct 4. 1929. Edmonton, AB, Canada. 168 p.

O’Donovan, J. T. 1996. Computerised decision support systems: aids to rational and sustainable weed management. Can. J. Plant Sci. 76:3-7.

O’Donovan, J. T., R. E. Blackshaw, K. N. Harker, and G. W. Clayton. 2006. Wheat seeding rate influences herbicide performance in wild oat (Avena fatua L.). Agron. J. 98:815-822.

O’Donovan, J. T., R. E. Blackshaw, K. N. Harker, G. W. Clayton, J. R. Moyer, L. M. Dosdall, D. C. Maurice, and T. K. Turkington. 2007. Integrated approaches to managing weeds in spring-sown crops in western Canada. Crop Protect. 26:390-398.

Powles, S. B. and J. M. Matthews. 1992. Multiple herbicide resistance in annual ryegrass (Lolium rigidum): a driving force for the adoption of integrated weed management strategies. Pages 75-87 in I. Denholm, A. L. Devonshire, and D. W. Hollomon, eds. Resistance 91: Achievements and Developments in Combating Pesticide Resistance. New York: Elsevier.

Powles, S. B. and Q. Yu. 2010. Evolution in action: plant resistance to herbicides. Ann. Rev. Plant Biol. 61:317-347.

Prokopy, R. J. 2003. Two decades of bottom-up, ecologically based pest management in a small commercial apple orchard in Massachusetts. Agric. Ecosyst. Environ. 94:299-309.
Radosevich, S. R. and C. M. Ghersa. 1992. Weeds, crops and herbicides: a modern-day "neckriddle". Weed Technol. 6:788-795.

Roush, M. L., S. R. Radosevich, and B. D. Maxwell. 1990. Future outlook for herbicide resistance research. Weed Technol. 4:208-214.

Shaw, W. C. 1982. Integrated weed management systems technology for pest management. Weed Sci. (Suppl.) 30:2-12.

Shirtliffe, S. J. and M. H. Entz. 2005. Chaff collection reduces seed dispersal of wild oat (Avena fatua) by a combine harvester. Weed Sci. 53:465-470.

Smith, R. G., D. A. Mortensen, and M. R. Ryan. 2009. A new hypothesis for the functional role of diversity in mediating resource pools and weed-crop competition in agroecosytems. Weed Res. 50:37-48.

Steckel, L. E., C. L. Main, A. T. Ellis, and T. C. Mueller. 2008. Palmer amaranth (Amaranthus palmeri) in Tennessee has low level glyphosate resistance. Weed Technol. 22:119-123.

Sutherland, S.J.M. 1991. Developing integrated weed management systems. Pages 47-59 in R. E. Blackshaw and L. M. Hall, eds. Integrated Weed Management: Explore the Potential. Sainte-Anne-de-Bellevue, QC: Expert Committee on Weeds.

Swanton, C. J., K. J. Mahoney, K. Chandler, and R. H. Gulden. 2008. Integrated weed management: knowledge-based weed management systems. Weed Sci. 56:168-172.

Swanton, C. J. and S. D. Murphy. 1996. Weed science beyond the weeds: the role of integrated weed management (IWM) in agroecosystem health. Weed Sci. 4:437-445.

Swanton, C. J. and S. F. Weise. 1991. Integrated weed management: the rationale and approach. Weed Technol. 5:657-663.

Thill, D. C., J. M. Lish, R. H. Callihan, and E. J. Bechinski. 1991. Integrated weed management - a component of integrated pest management: a critical review. Weed Technol. 5:648-656.

Thomas, A. G., A. Légère, J. Y. Leeson, F. C. Stevenson, and F. A. Holm. 2010. Weed community response to contrasting integrated weed management systems for cool dryland annual crops. Weed Res. 51:41-50.

Walker, R. H. and G. A. Buchanan. 1982. Crop manipulation in integrated weed management systems. Weed Sci. (Suppl.) 30:17-24.

Walsh, M. J., R. B. Harrington, and S. B. Powles. 2012. Harrington seed destructor: a new nonchemical weed control tool for global grain crops. Crop Sci. 52:1343-1347.

Wang, L., S. Gruber, and W. Claupein. 2012. Effects of woodchip mulch and barley intercropping on weeds in lentil crops. Weed Res. 52:161-168.

Westerman, P. R., M. Liebman, F. D. Menalled, A. H. Heggenstaller, R. G. Hartzler, and P. M. Dixon. 2005. Are many little hammers effective? Velvetleaf (Abutilon theophrasti) population dynamics in two- and four-year crop rotation systems. Weed Sci. 53:382-392.

Wyse, D. L. 1992. Future of weed science research. Weed Technol. 6:162-165.

Xue, Q. and R. N. Stougaard. 2006. Effects of spring wheat seed size and reduced rates of tralkoxydim on wild oat control, wheat yield, and economic returns. Weed Technol. 20:472-477.

Young, F. L., D. A. Ball, D. C. Thill, R. Alldredge, A. G. Ogg, Jr., and S. S. Seefeldt. 2010. Integrated weed management systems identified for jointed goatgrass (Aegilops cylindrica) in the Pacific Northwest. Weed Technol. $24: 430-439$

Zimdahl, R. L. 1994. Who are you and where are you going? Weed Technol. 8:388-391.

Received July 30, 2012, and approved September 18, 2012. 